\title{
Role of clay properties in improvement using small stone piles
}

1 Gopinathan Pillai Hari MTech

Research Scholar, Department of Civil Engineering, National Institute of Technology, Calicut, India (corresponding author: harivallikkavu@gmail.com)
2 Natesan Sankar PhD

Professor, Department of Civil Engineering, National Institute of Technology, Calicut, India

3. Sridhar Chandrakaran PhD

Professor, Department of Civil Engineering, National Institute of Technology, Calicut, India
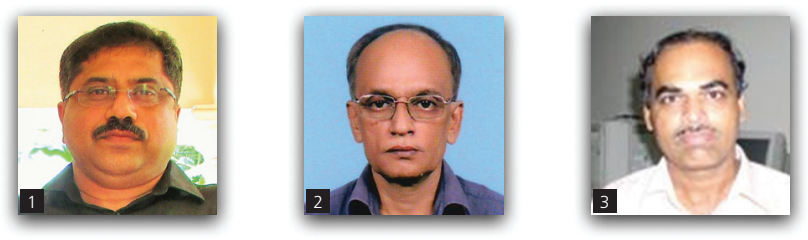

Ground improvement using group floating stone compaction piles with a small replacement area ratio is an effective solution for improving soft clay for construction of buildings with up to two storeys. Sufficient data based on field studies for the improvement of the ground using stone compaction piles with a smaller diameter and low area replacement ratios are not available. This study was intended to create a database for assessing the improvement of clay ground and predicting the suitability of group floating compaction piles with granular materials for the improvement of clay ground based on the properties of clay. Twelve sites were selected for conducting the study. The effects of different soil properties such as sensitivity, liquidity index and consistency index on the improvement of the undrained shear strength of clay were investigated. Also, a correlation of standard penetration test values before and after the improvements was arrived at based on field observations. The results are discussed in this paper.

\section{Notation}

$A_{\mathrm{s}} \quad$ replacement area ratio

$C_{\mathrm{I}} \quad$ consistency index

$d \quad$ diameter of stone compaction piles

$L_{\mathrm{I}} \quad$ liquidity index

$L_{\mathrm{L}} \quad$ liquid limit

$N \quad$ standard penetration test value

$P_{\mathrm{I}} \quad$ plasticity index

$P_{\mathrm{L}} \quad$ plastic limit

$q_{\mathrm{c}} \quad$ static cone resistance

$S \quad$ sensitivity of soil

$s_{\mathrm{u}} \quad$ undrained shear strength of clay

$Z \quad$ depth of soil

$\emptyset \quad$ angle of internal friction

\section{Introduction}

When a very soft clay ground with low shear strength and high plasticity characteristics is encountered, even the construction of a light structure becomes a teasing problem for geotechnical engineers. Pile foundation or mat foundation needs to be provided even for a lighter structure. Ground improvement using group floating stone compaction piles with a smaller diameter and a low replacement area ratio is effectively used for the construction of residential buildings with up to two storeys to counter the low shear strength and the high compressibility of the soil. The additional cost involved is about $2 \%$ of the total cost of the construction of the structure.

Floating stone compaction piles (SCPs) with a small replacement area ratio are constructed by driving an empty steel casing pipe with a concrete plug made of M20 concrete placed at the bottom of the steel casing pipe. A concrete plug with a diameter of $88 \mathrm{~mm}$ and a conical shape for the bottom half is placed at the bottom groove of a steel casing pipe with a $100 \mathrm{~mm}$ external dia. and a $12 \mathrm{~mm}$ thickness, as shown in Figure 1. The steel casing pipe is driven to the desired depth by using a dropping hammer. During the downward motion, the concrete cone prevents the soil from entering the steel casing pipe. After the steel casing pipe reaches the required depth, $6 \mathrm{~mm}$ broken stones are fed into the casing pipe from the top. The steel pipe is then gradually lifted up using a mechanical winch. The concrete plug will remain at the bottom of the SCP. During the withdrawal of the steel pipe, a stroking motion is imparted to the steel pipe to compact the broken stones inside the SCPs. Jetting of water is done through 
Geotechnical Research

Volume 3 Issue 1
Role of clay properties in improvement

using small stone piles

Hari, Sankar and Chandrakaran

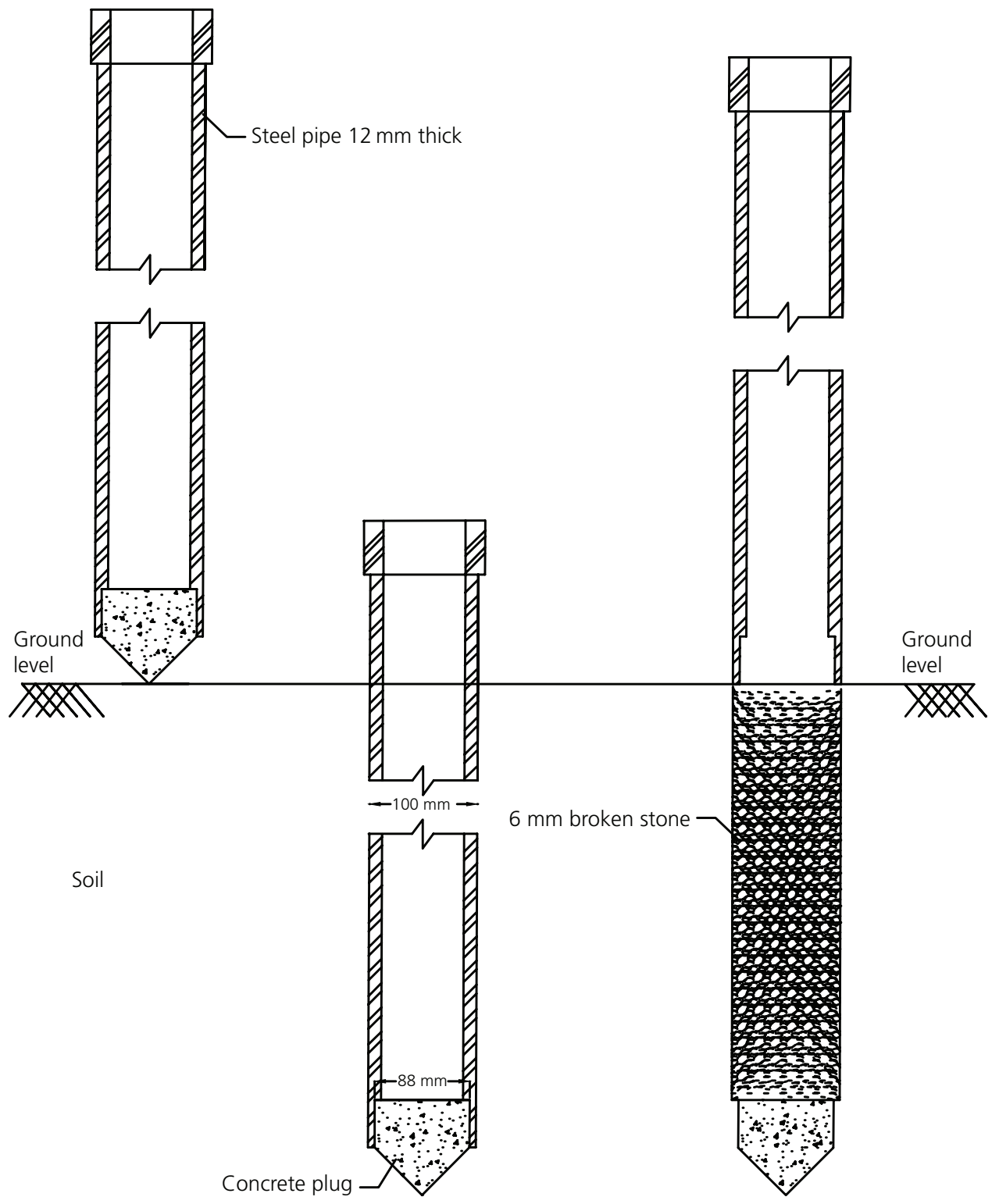

Figure 1. Schematic diagram showing the functioning of a

concrete plug

the casing pipe as shown in Figures 2 and 3. This is an added help for getting proper compaction.

Most studies have investigated sand/stone compaction piles with larger replacement area ratios varying from 30 to $70 \%$, having a diameter of more than $300 \mathrm{~mm}$ and a larger spacing (Kitazume, 2005). But for SCPs with a smaller diameter of $100 \mathrm{~mm}$ and an area replacement ratio less than $10 \%$, sufficient field research data are not available. Research studies based on the soil properties are also limited. This study was intended to create a database for soft clay ground improved with group floating SCPs with a low area replacement ratio and with a smaller diameter of $100 \mathrm{~mm}$. The main objective of the study was to establish the role of soil properties like sensitivity, liquidity index and consistency index in increasing the shear strength of clay ground improved with floating SCPs.

Studies proved that the length-to-diameter $(L / d)$ ratio could affect the performance of a vibrated stone column (Kitazume, 2005; Sivakumar et al., 2004). Shorter columns $(L / d$ ratio < 6) produced adequate capacity, while longer columns were helpful in reducing the settlement. For short columns, the major fraction of the load applied would be transferred to the base of the column, and the failure pattern would be punching in soft clays (Ambily and Gandhi, 2007; Serridge and Sarsby, 2009). In the case of long columns, bulging occurred at shallow depths, and the load transfer to the base only occurred at high footing pressures. 
Role of clay properties in improvement using small stone piles

Hari, Sankar and Chandrakaran

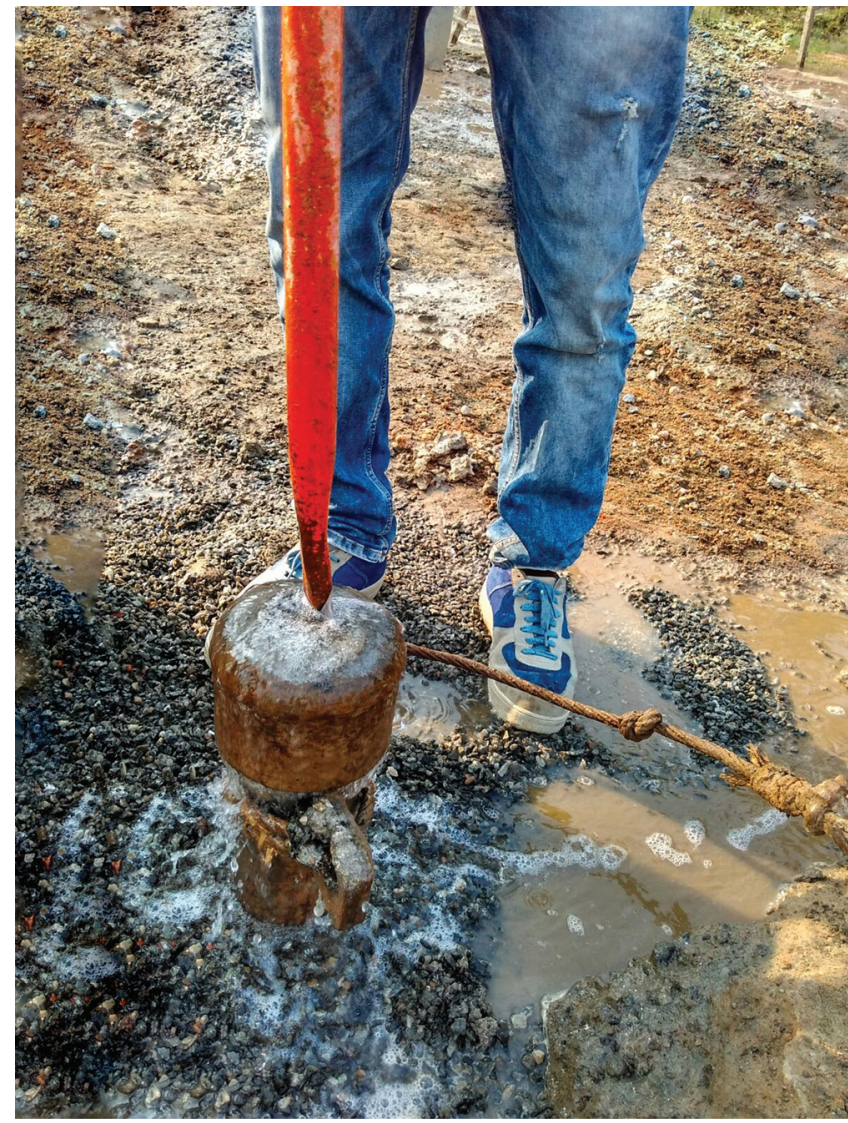

Figure 2. Photograph showing water jetting in to a steel pipe filled with $6 \mathrm{~mm}$ broken stones

The smear zone around the sand compaction piles has a notable effect on improving the shear strength of clay (Aboshi et al., 1991). The soil properties around the installed stone piles are affected by the installation process, mainly the pore pressure dissipation (Juneja et al., 2013). The process of SCP installation affects the on-site clay in two ways. First, the clay fabric immediately surrounding the SCP is remoulded and disturbed, leading to the development of large shear strains in this zone of around 45\% (Guetif et al., 2007). The disturbance in this zone depends on the column diameter and the tools used in the installation (Black et al., 2006). Second, the clay is laterally compressed to accommodate the sand column and thus increases the coefficient of the lateral earth pressure. The compression zone extends up to two to three times the pile diameter and depends on the diameter of the casing, as well as the final sand column and the depth from the surface (Lee et al., 2004). But the factor of increase depends on the type of soil, the spacing and the method of installation of the stone columns. Field measurements had indicated higher pore pressures during the installation stages (Castro and Sagaseta, 2009). Later, these pore pressures dissipated and the values increased with depth, and the authors consider the increase in undrained shear strength as an explanation for this effect. The authors observed that the areas affected by the installation of the piles remain unchanged with depth and were around $13 \cdot 5$ times the column radius.

Detailed experimental field studies were carried out to investigate the effect of different soil properties on the shear strength behaviour of clayey soil. Various soil properties affecting the increase in the undrained shear strength of clay were studied. This paper describes the details of the experimental work carried out and discusses the results. In this paper, when the term SCP is used, it means the group floating stone compaction piles of smaller diameter with low replacement area ratio.

\section{Programme of field study}

Twelve sites in the coastal belt of Kerala, India, were selected for conducting the study. All the sites were predominantly cohesive in

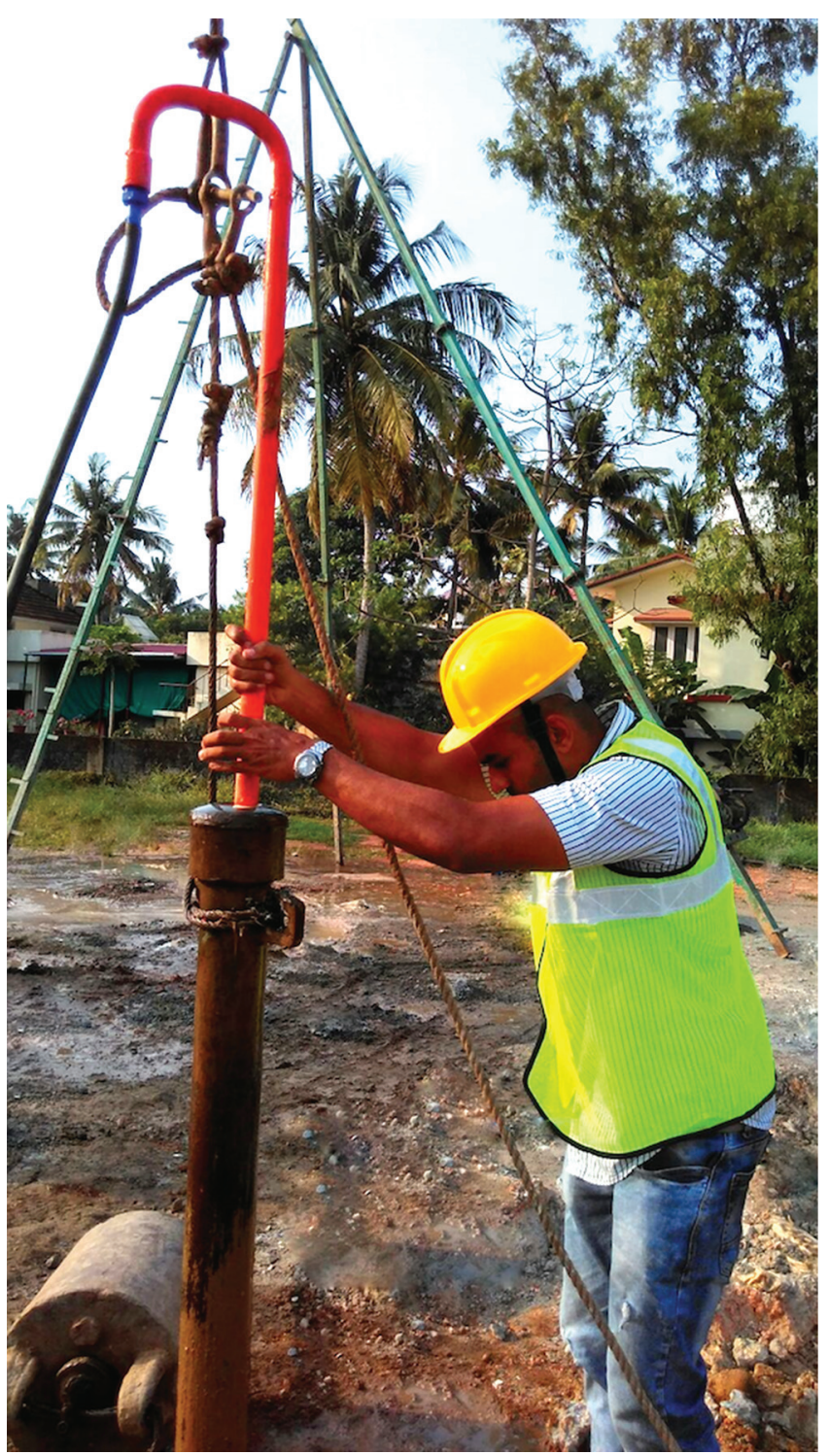

Figure 3. Photograph showing a water-jetting arrangement during the lifting up of a steel pipe 
nature with varying soil properties. Field studies were conducted at all the sites before and after the improvement of the soil for up to 2 years at different time intervals. Laboratory tests were also carried out on the undisturbed soil samples collected from various depths.

\section{Details of SCPs}

The patterns of the provision of SCP were kept constant in all 12 sites. SCPs of $100 \mathrm{~mm}$ dia. were installed up to a depth of $5.0 \mathrm{~m}$ at a spacing of $300 \mathrm{~mm}$ centre to centre $(\mathrm{c} / \mathrm{c})$ in a triangular pattern. Concrete plugs were provided at the bottom. Broken granite stones $6 \mathrm{~mm}$ in size were used as a granular material for the construction of SCP. The replacement area ratio was kept as $8 \cdot 72 \%$.

\section{Field tests}

Standard penetration tests (SPTs), field vane shear tests (FVSTs) and static cone penetration tests (SCPTs) were carried out at all sites before and after the improvement of the clay ground with SCPs. SPTs were carried out at $1.0 \mathrm{~m}$ depth intervals up to $5.0 \mathrm{~m}$ depth, before the installation of SCPs. After providing SCPs, the SPTs were carried at time intervals of $1 \mathrm{~d}, 1.5$ months, 3 months, 6 months, 1 year and 2 years respectively at the centre of the triangular area between the SCPs installed. After the installation of SCPs, STPs were conducted at the centre of the stone compaction piles, after $1 \mathrm{~d}$ and after 6 months respectively. SCPTs were carried out before and after providing SCPs at different time intervals: $1 \mathrm{~d}$, $45 \mathrm{~d}, 3$ months, 6 months, 1 year and 2 years respectively at the centre of the triangular area between the SCPs and near the SCPs.

The sensitivity of the clay at $1.0 \mathrm{~m}$ depth intervals up to a $5.0 \mathrm{~m}$ depth was determined by conducting FVSTs before improving the ground with SCPs. The undrained shear strength of the clay was determined after applying the corrections given by Lunne and Eide (cited by Bowles (1997)) to the static cone resistance $\left(q_{\mathrm{c}}\right)$ values obtained by conducting the SCPT.

\section{Laboratory tests}

The undisturbed samples were collected from different depths before improving the ground with SCPs. The field density, the natural moisture content (NMC), the gradation of the soil, the liquid limit and the plastic limit were determined in the laboratory according to IS 2720 (BIS, 1973, 1985a, 1985b).

\section{Results and interpretations}

The SPT results are presented in Table 1 . The results of laboratory tests, SCPTs and FVSTs are shown in Table 2. The SPT and SCPT results after the improvement of the clay ground with SCPs at different time intervals indicate that the improvement in the shear strength of the clay after 6 months is negligible. So the results obtained from different tests carried out 6 months after the improvement are mainly used for the further discussions.

\section{Standard penetration test}

It can be observed from Table 1 that the $N$ value obtained on SCPs immediately after their installation is lower compared to the $N$ values obtained after 6 months. This is mainly due to the reduction in the lateral earth pressure because of the excessive strains developed in the soil surrounding the SCPs during the installation of the piles. Laboratory test results of granular material used for SCPs, $6 \mathrm{~mm}$ broken stones, gave very high values for the angle of internal friction (ø): up to $50-55^{\circ}$. But the SPTs conducted on SCPs gave lower $N$ values. The lower $N$ values on the SCP are due to the smaller diameter of the SCPs and the subsequent reduction in confinement. In the case of smaller-diameter stone compaction piles, for design, it is better to go for lower $\varnothing$ values for the broken stones based on the lower $N$ values obtained from the SCPs. It can be observed from Table 1 that the average $N$ value obtained from up to $3.0 \mathrm{~m}$ depths on SCPs, 6 months after the improvement, is 12. Based on the average $N$ value obtained after 6 months from the SCPs and the different correlations of $\varnothing$ and $N$ values by Sabatini et al. (2002), Schmertmann (1975) and Kulhawy and Mayne (1990) (Sheahan et al., 2011), the angle of internal friction (ø) of the broken stone material can be taken as two or three times that of the laboratory $\varnothing$ value of the broken stones.

Figure 4 indicates the variation in the $N$ values obtained at the centre of the triangular area between the SCPs before the improvement and 6 months after the improvement of the clay ground. There are improvements in the $N$ values. This improvement is caused by the increase in the shear strength by the dissipation of the pore pressure developed due to shear strains developed during the driving disturbances. The improvement in the $N$ value can be expressed by the following equation (240 data)

1. $N_{\text {after }}=1 \cdot 22 N_{\text {before }}+1 \cdot 12$

\section{Sensitivity}

Sensitivity is a characteristic of cohesive soil and is defined as the ratio of the shear strength of undisturbed clay to the shear strength of remoulded clay. The results indicate that the improvement in the undrained shear strength of clay depends on the sensitivity of the soil. It can be observed from Figure 5 that near the SCPs, the undrained shear strength of clay increases as the sensitivity of clay decreases. The percentage increase in the undrained shear strength near the SCPs can be represented by the following equation

2. $\% \Delta s_{\mathrm{u}}=48 \cdot 6-8.4 S$

Figure 6 illustrates that at the centre of the triangular area between the SCPs, the undrained shear strength increases as the sensitivity of the soil decreases, but the increase is lower compared to that near the SCPs. The percentage increase in the undrained shear strength can be expressed by the following equation

3. $\% \Delta s_{\mathrm{u}}=26 \cdot 8-5 \cdot 3 S$

The average increase in the undrained shear strength near the SCPs and at the centre between the SCPs can be taken by arriving at the bearing capacity of soil. 


\begin{tabular}{|c|c|c|c|c|c|c|c|c|c|c|c|}
\hline & \multirow{2}{*}{$\begin{array}{c}\text { Depth: } \\
\text { m }\end{array}$} & \multirow{2}{*}{$\begin{array}{c}N \text { value } \\
\text { before the } \\
\text { improvement }\end{array}$} & \multicolumn{6}{|c|}{$N$ value after the improvement between the SCPS } & \multicolumn{2}{|c|}{$N$ value on pile } & \multirow{2}{*}{$\begin{array}{c}\text { Fine } \\
\text { content: \% }\end{array}$} \\
\hline & & & Id & $\begin{array}{c}1.5 \\
\text { months }\end{array}$ & $\begin{array}{c}3 \cdot 0 \\
\text { months }\end{array}$ & $\begin{array}{c}6.0 \\
\text { months }\end{array}$ & 1 year & 2 years & $1 d$ & $\begin{array}{l}\text { After } 6 \\
\text { months }\end{array}$ & \\
\hline \multirow[t]{5}{*}{ Site 1} & 1 & 3 & 4 & 5 & 6 & 6 & 6 & 6 & 8 & 12 & $59 \cdot 6$ \\
\hline & 2 & 1 & 1 & 2 & 2 & 3 & 3 & 3 & 7 & 11 & $89 \cdot 2$ \\
\hline & 3 & 1 & 1 & 2 & 2 & 2 & 2 & 2 & 6 & 11 & $93 \cdot 5$ \\
\hline & 4 & 2 & 1 & 2 & 3 & 3 & 3 & 3 & 5 & 8 & $95 \cdot 2$ \\
\hline & 5 & 1 & 1 & 1 & 2 & 2 & 2 & 2 & 2 & 2 & $95 \cdot 4$ \\
\hline \multirow[t]{5}{*}{ Site 2} & 1 & 5 & 5 & 7 & 7 & 7 & 7 & 7 & 10 & 16 & $40 \cdot 1$ \\
\hline & 2 & 4 & 3 & 5 & 6 & 6 & 6 & 6 & 8 & 12 & $56 \cdot 0$ \\
\hline & 3 & 2 & 2 & 3 & 4 & 4 & 4 & 4 & 7 & 10 & $92 \cdot 7$ \\
\hline & 4 & 3 & 2 & 4 & 4 & 4 & 4 & 5 & 6 & 9 & $93 \cdot 1$ \\
\hline & 5 & 3 & 2 & 3 & 4 & 4 & 4 & 4 & 4 & 5 & $96 \cdot 9$ \\
\hline \multirow[t]{5}{*}{ Site 3} & 1 & 3 & 4 & 5 & 5 & 5 & 5 & 5 & 8 & 10 & $70 \cdot 4$ \\
\hline & 2 & 1 & 1 & 2 & 3 & 3 & 3 & 3 & 6 & 8 & 88.5 \\
\hline & 3 & 3 & 2 & 4 & 5 & 5 & 5 & 5 & 7 & 9 & $77 \cdot 7$ \\
\hline & 4 & 2 & 1 & 2 & 3 & 4 & 4 & 4 & 6 & 7 & $94 \cdot 8$ \\
\hline & 5 & 1 & 0 & 1 & 2 & 2 & 2 & 2 & 2 & 3 & 94.9 \\
\hline \multirow[t]{5}{*}{ Site 4} & 1 & 5 & 4 & 5 & 6 & 7 & 7 & 7 & 9 & 12 & $77 \cdot 1$ \\
\hline & 2 & 1 & 1 & 2 & 3 & 3 & 3 & 3 & 8 & 12 & 78.7 \\
\hline & 3 & 0 & 0 & 1 & 2 & 2 & 2 & 2 & 6 & 9 & $92 \cdot 2$ \\
\hline & 4 & 1 & 1 & 2 & 2 & 2 & 2 & 2 & 6 & 9 & $95 \cdot 2$ \\
\hline & 5 & 2 & 1 & 1 & 2 & 2 & 2 & 3 & 3 & 4 & $95 \cdot 4$ \\
\hline \multirow[t]{5}{*}{ Site 5} & 1 & 6 & 4 & 6 & 8 & 8 & 8 & 8 & 12 & 16 & $77 \cdot 1$ \\
\hline & 2 & 1 & 1 & 2 & 3 & 3 & 3 & 3 & 7 & 11 & 78.7 \\
\hline & 3 & 1 & 0 & 1 & 2 & 2 & 2 & 2 & 6 & 9 & $92 \cdot 2$ \\
\hline & 4 & 0 & 0 & 1 & 2 & 2 & 2 & 2 & 5 & 8 & $95 \cdot 2$ \\
\hline & 5 & 0 & 0 & 1 & 1 & 2 & 2 & 2 & 2 & 3 & 95.4 \\
\hline \multirow[t]{5}{*}{ Site 6} & 1 & 7 & 6 & 8 & 9 & 9 & 9 & 9 & 11 & 18 & $72 \cdot 4$ \\
\hline & 2 & 1 & 1 & 2 & 2 & 3 & 3 & 3 & 8 & 13 & $77 \cdot 9$ \\
\hline & 3 & 2 & 1 & 2 & 3 & 3 & 3 & 3 & 8 & 12 & $94 \cdot 8$ \\
\hline & 4 & 1 & 0 & 1 & 2 & 2 & 2 & 2 & 6 & 10 & $96 \cdot 0$ \\
\hline & 5 & 1 & 1 & 2 & 2 & 2 & 2 & 2 & 3 & 4 & $96 \cdot 4$ \\
\hline \multirow[t]{5}{*}{ Site 7} & 1 & 6 & 7 & 9 & 9 & 9 & 9 & 9 & 12 & 20 & $68 \cdot 2$ \\
\hline & 2 & 6 & 7 & 9 & 9 & 9 & 9 & 9 & 10 & 16 & $73 \cdot 4$ \\
\hline & 3 & 5 & 4 & 6 & 7 & 7 & 7 & 7 & 8 & 12 & 88.7 \\
\hline & 4 & 3 & 2 & 4 & 5 & 5 & 5 & 5 & 7 & 10 & $94 \cdot 2$ \\
\hline & 5 & 4 & 3 & 5 & 6 & 7 & 7 & 7 & 5 & 7 & $95 \cdot 8$ \\
\hline \multirow[t]{5}{*}{ Site 8} & 1 & 8 & 9 & 10 & 10 & 10 & 10 & 10 & 14 & 22 & $51 \cdot 1$ \\
\hline & 2 & 6 & 6 & 8 & 9 & 9 & 9 & 9 & 10 & 17 & $61 \cdot 8$ \\
\hline & 3 & 3 & 3 & 5 & 6 & 6 & 6 & 6 & 8 & 12 & $81 \cdot 4$ \\
\hline & 4 & 2 & 1 & 3 & 4 & 4 & 4 & 4 & 5 & 8 & $94 \cdot 6$ \\
\hline & 5 & 1 & 0 & 2 & 2 & 2 & 2 & 2 & 4 & 6 & 95.4 \\
\hline \multirow[t]{5}{*}{ Site 9} & 1 & 4 & 3 & 5 & 6 & 6 & 7 & 7 & 8 & 12 & $67 \cdot 3$ \\
\hline & 2 & 3 & 3 & 4 & 5 & 5 & 5 & 5 & 6 & 8 & $71 \cdot 3$ \\
\hline & 3 & 2 & 1 & 2 & 3 & 4 & 4 & 4 & 5 & 7 & 93.7 \\
\hline & 4 & 2 & 1 & 2 & 3 & 3 & 3 & 3 & 5 & 8 & $94 \cdot 8$ \\
\hline & 5 & 1 & 0 & 1 & 1 & 2 & 1 & 1 & 3 & 5 & $95 \cdot 9$ \\
\hline
\end{tabular}

Table 1. SPT values of SCP-improved clay ground before and after the improvement up to 2 years ( $1 \mathrm{~d}, 1.5$ months, 3 months, 6 months, 1 year and 2 years) (continued on next page) 


\begin{tabular}{|c|c|c|c|c|c|c|c|c|c|c|c|}
\hline & \multirow{2}{*}{$\begin{array}{c}\text { Depth: } \\
\text { m }\end{array}$} & \multirow{2}{*}{$\begin{array}{c}N \text { value } \\
\text { before the } \\
\text { improvement }\end{array}$} & \multicolumn{6}{|c|}{$N$ value after the improvement between the SCPS } & \multicolumn{2}{|c|}{$N$ value on pile } & \multirow{2}{*}{$\begin{array}{c}\text { Fine } \\
\text { content: \% }\end{array}$} \\
\hline & & & ld & $\begin{array}{c}1.5 \\
\text { months }\end{array}$ & $\begin{array}{c}3 \cdot 0 \\
\text { months }\end{array}$ & $\begin{array}{c}6.0 \\
\text { months }\end{array}$ & 1 year & 2 years & $1 d$ & $\begin{array}{l}\text { After } 6 \\
\text { months }\end{array}$ & \\
\hline \multirow[t]{5}{*}{ Site 10} & 1 & 4 & 4 & 5 & 6 & 7 & 7 & 7 & 9 & 14 & $72 \cdot 5$ \\
\hline & 2 & 4 & 3 & 4 & 6 & 6 & 6 & 6 & 8 & 14 & $73 \cdot 9$ \\
\hline & 3 & 2 & 1 & 3 & 4 & 5 & 5 & 5 & 6 & 11 & $92 \cdot 1$ \\
\hline & 4 & 2 & 1 & 2 & 2 & 3 & 3 & 3 & 4 & 8 & $94 \cdot 8$ \\
\hline & 5 & 1 & 0 & 1 & 1 & 2 & 2 & 2 & 3 & 4 & $95 \cdot 4$ \\
\hline \multirow[t]{5}{*}{ Site 11} & 1 & 3 & 3 & 4 & 5 & 5 & 5 & 5 & 5 & 8 & $70 \cdot 3$ \\
\hline & 2 & 2 & 1 & 2 & 3 & 3 & 4 & 4 & 5 & 6 & $87 \cdot 9$ \\
\hline & 3 & 1 & 0 & 1 & 2 & 2 & 2 & 3 & 4 & 7 & $93 \cdot 2$ \\
\hline & 4 & 1 & 0 & 1 & 2 & 2 & 2 & 2 & 4 & 6 & $97 \cdot 8$ \\
\hline & 5 & 0 & 0 & 0 & 0 & 1 & 1 & 1 & 2 & 3 & $98 \cdot 2$ \\
\hline \multirow[t]{5}{*}{ Site 12} & 1 & 4 & 3 & 6 & 7 & 7 & 7 & 7 & 9 & 16 & $69 \cdot 2$ \\
\hline & 2 & 2 & 1 & 2 & 3 & 3 & 4 & 4 & 6 & 11 & $85 \cdot 8$ \\
\hline & 3 & 2 & 0 & 1 & 2 & 2 & 2 & 2 & 5 & 9 & $92 \cdot 7$ \\
\hline & 4 & 2 & 0 & 1 & 2 & 2 & 2 & 2 & 4 & 6 & $95 \cdot 7$ \\
\hline & 5 & 1 & 0 & 1 & 1 & 1 & 1 & 1 & 2 & 4 & $97 \cdot 5$ \\
\hline
\end{tabular}

Table 1. Continued

Higher sensitivity is due to the loss of shear strength in remoulding because of the higher liquidity and the breaking down of the original structure of the soil during remoulding. For clays having lower sensitivity, the liquidity is low, and due to that the shear strain produced will be larger. As the sensitivity of the soil increases, due to increasing liquidity, lower shear strain will be produced. When the sensitivity is more than $5 \cdot 5$, no shear strain will be caused by the installation of the SCPs. As mentioned earlier, the increase in the shear strength of clay is due to the dissipation of the pore pressure developed from the shear strain produced during the installation of SCPs.

From the variation in the percentage increase in undrained shear strength and the sensitivity of soil, it can be observed that when the sensitivity of clay is greater than $5 \cdot 5$, the improvement in the undrained shear strength of clay is negligible. For clays with a sensitivity of $>5 \cdot 5$, no improvement in shear strength can be achieved by the installation of SCPs. In that case, the increase in shear strength comes only from the shear strength of the SCPs, which is a smaller amount due to their low replacement area ratio. So for clays with a sensitivity of more than 5.5, ground improvement using SCPs is not a feasible option. In that case, it is better to go for pre-loading after providing sufficient vertical drains.

\section{Liquidity index}

Figure 7 gives the variation in the liquidity index and the percentage increase in the undrained shear strength of clay improved with SCPs. The decrease in the liquidity index of the clay causes improvement in the undrained shear strength of the clay. The relation between the percentage increase in the undrained shear strength and the liquidity index can be expressed by the following two equations

near SCPs

4. $\% \Delta s_{\mathrm{u}}=37 \cdot 8-0 \cdot 285 L_{\mathrm{I}}$

- centre between SCPs

5. $\% \Delta s_{\mathrm{u}}=20 \cdot 15-0 \cdot 187 L_{\mathrm{I}}$

The liquidity index of soil indicates the relative difference between the NMC of the soil and the plastic limit of the soil. As the liquidity index of the soil approaches $100 \%$ (i.e. NMC is near the liquid limit), the soil considerably loses its shear strength and begins to behave as a liquid. At this stage, the driving of the casing pipe causes little lateral displacement of clay. So the setting-up effect of the clay will not take place. So there will not be any noticeable increase in the undrained shear strength of the clay.

\section{Consistency index}

The variation in the consistency index with percentage increase in the undrained shear strength of soil is displayed in Figure 8. It shows that the undrained shear strength of clay is increasing as the consistency index is increased. When soil has $100 \%$ consistency index (i.e. the water content is at plastic limit), the increase in $s_{\mathrm{u}}$ near the SCPs and at the centre between the SCPs are at around $40 \%$ and at around $20 \%$ respectively. As the consistency index approaches zero, the improvement in the undrained shear strength of the clay becomes negligible. The 


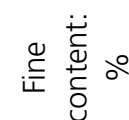

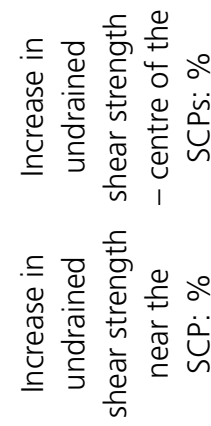

๙̊

$\ddot{U}$

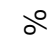

$\ddot{-}$

๙ㅇ

$\dot{2}$

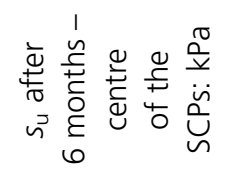

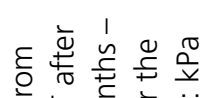

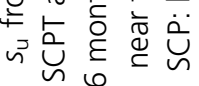

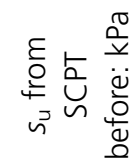

$n$

:

우

$\ddot{a}$

웅

$\ddot{\exists}$

○인

$\sum_{\Sigma}^{\ddot{z}}$

$\varepsilon$

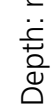

竞

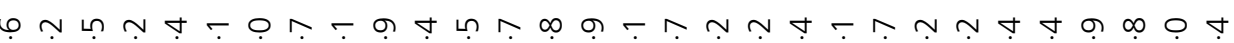

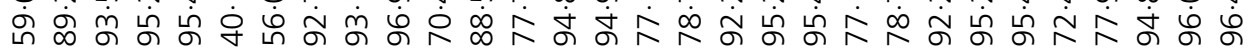

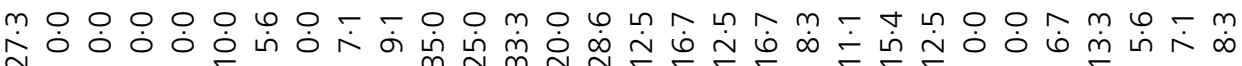

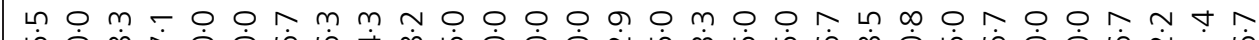

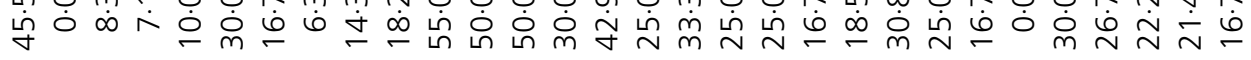

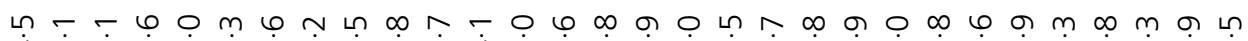

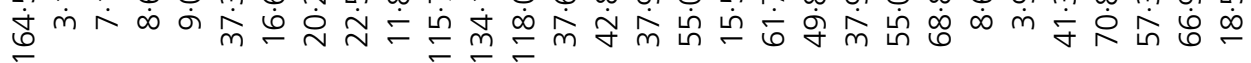

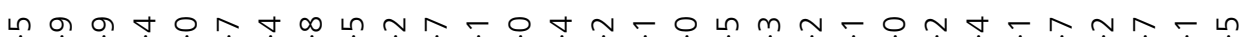

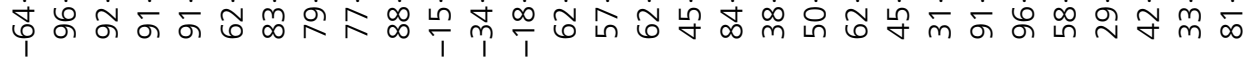

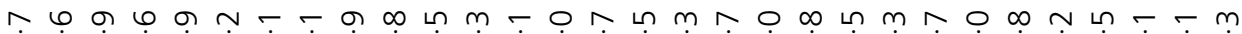

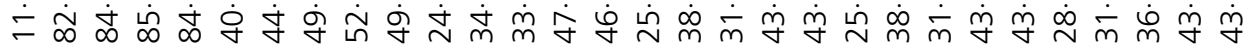

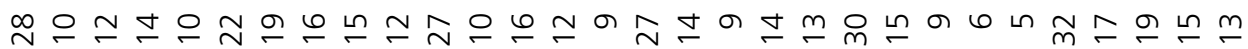

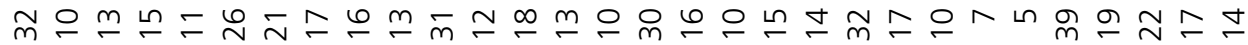

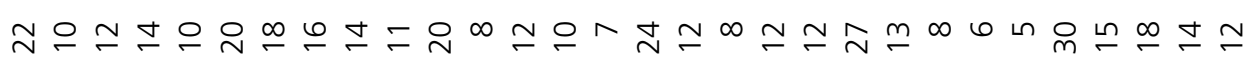

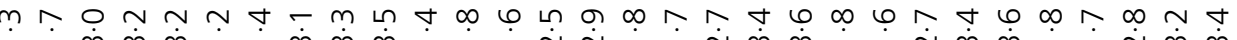
$\dot{-} \dot{\sim} \dot{m} \dot{m} \dot{m} \dot{\sim} \dot{m} \dot{m} \dot{m} \dot{\sim} \dot{\leftarrow} \dot{\sim} \dot{N} \dot{N} \dot{-} \dot{\sim} \dot{N} \dot{m} \dot{m} \dot{\leftarrow} \dot{\sim} \dot{N} \dot{m} \dot{m} \dot{-} \dot{\sim} \dot{N} \dot{m} \dot{m}$

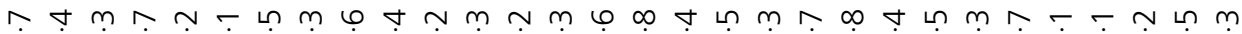
ல் ப் ம் ம்

$\forall 0 \sim m-m \varphi+n N \wedge \varphi m m m m \wedge N m\llcorner m \wedge N m L m \varphi m \varphi 6$

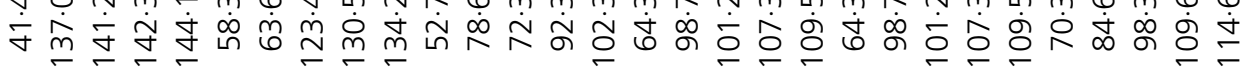

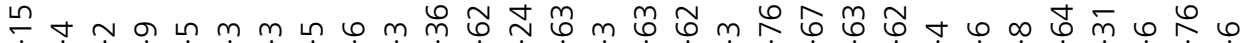

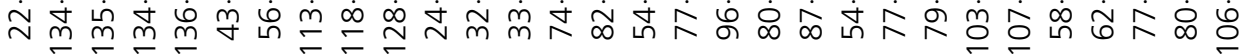

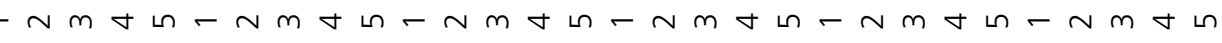




\begin{tabular}{|c|c|}
\hline 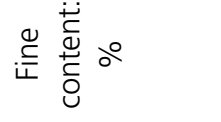 & 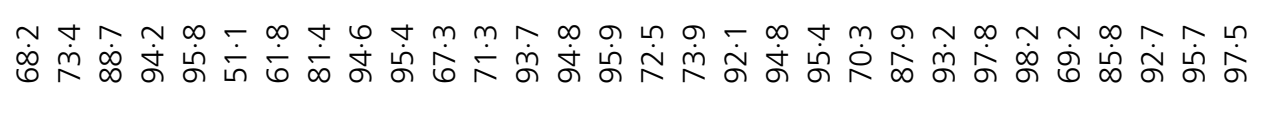 \\
\hline 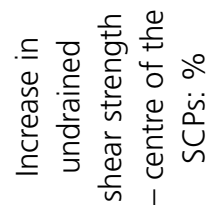 & 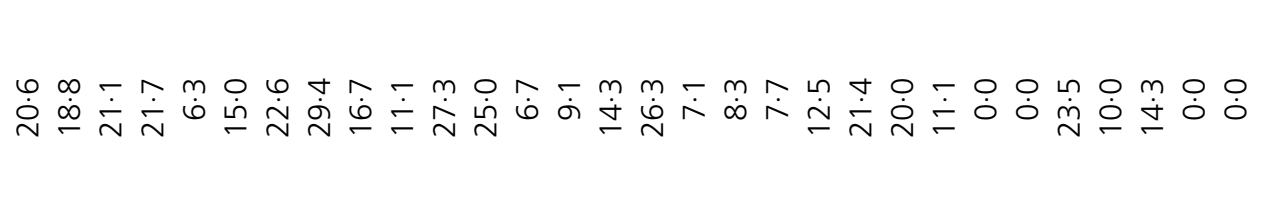 \\
\hline 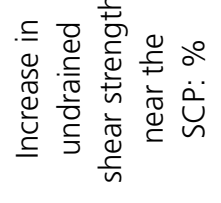 & 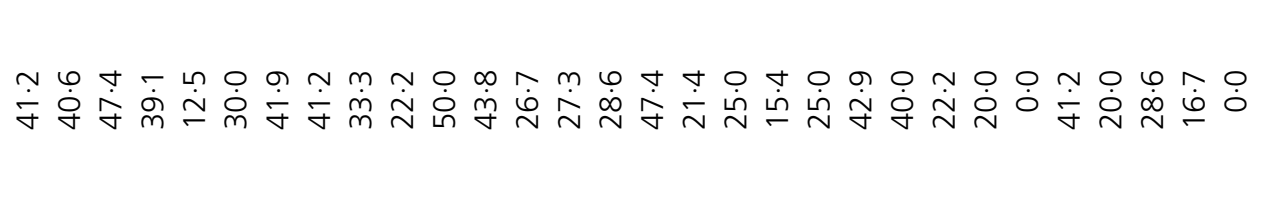 \\
\hline & 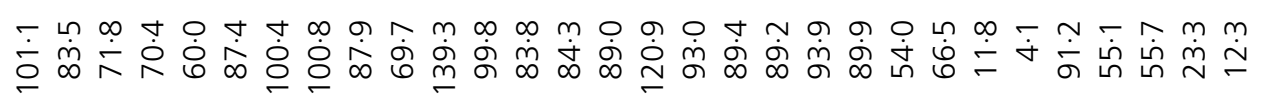 \\
\hline$\stackrel{\circ}{\stackrel{2}{-}}$ & 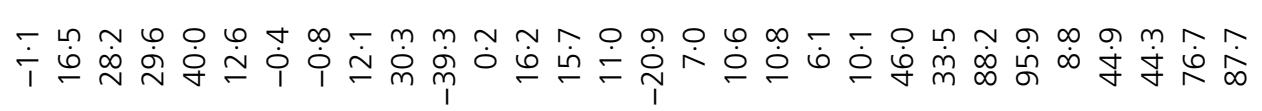 \\
\hline ○̊ & 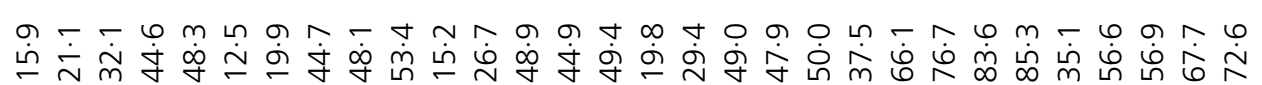 \\
\hline 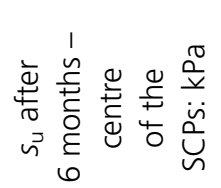 & 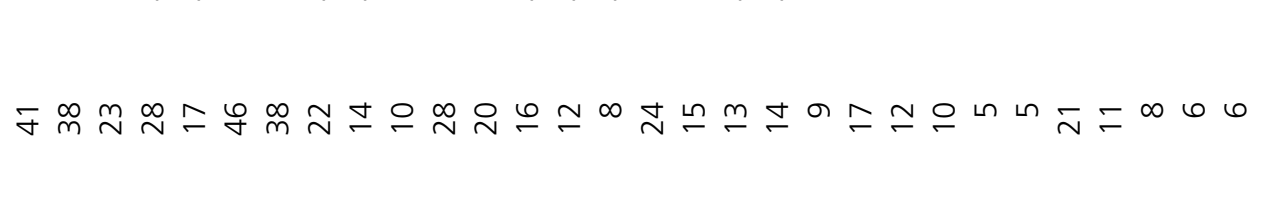 \\
\hline 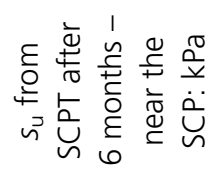 & 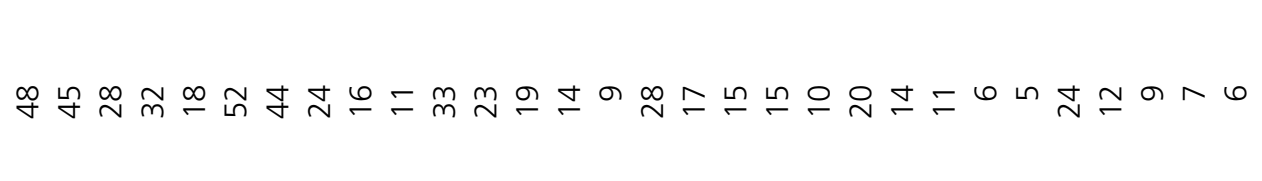 \\
\hline 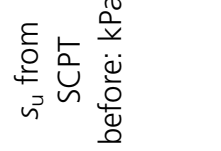 & 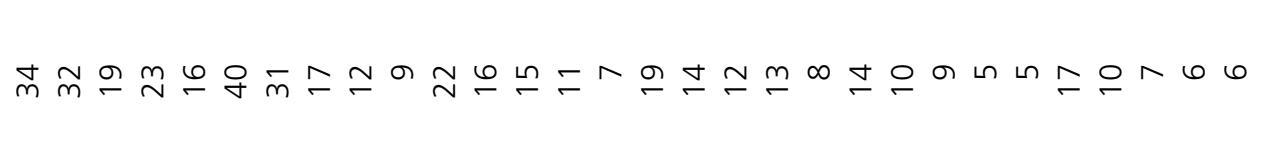 \\
\hline 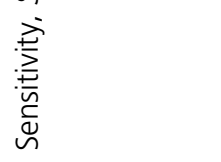 & 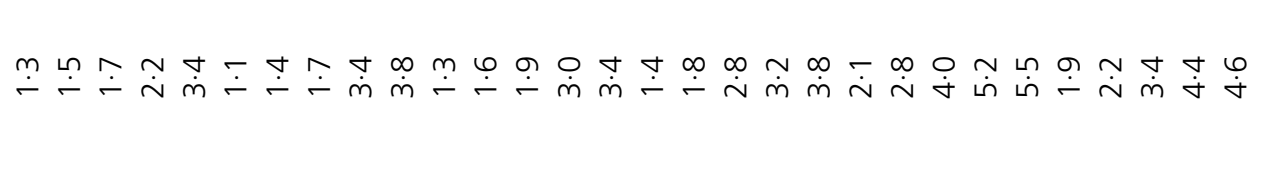 \\
\hline$\stackrel{2}{\circ}$ & 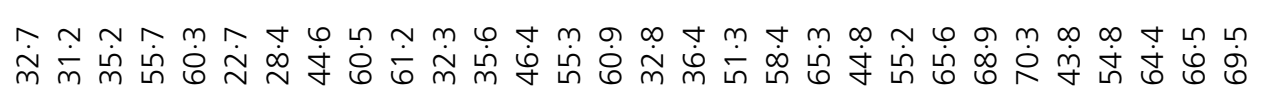 \\
\hline ○̊ & 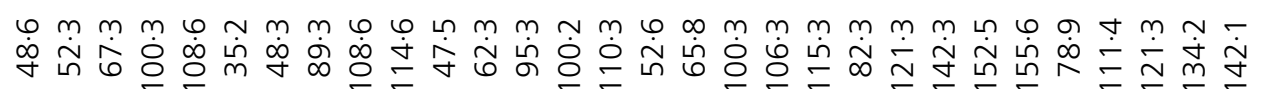 \\
\hline$\stackrel{\circ}{\circ}$ & 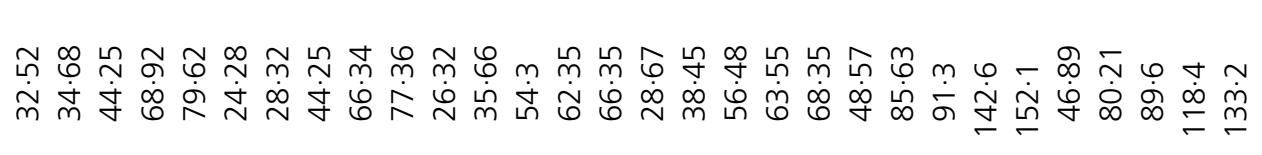 \\
\hline द. & \\
\hline$\frac{2}{\vec{t}}$ & 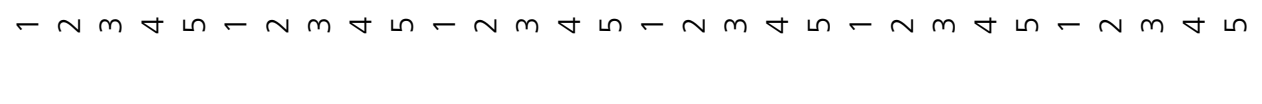 \\
\hline$\stackrel{\oplus}{\hbar}$ & $a \quad \stackrel{ }{\circ}$ \\
\hline
\end{tabular}




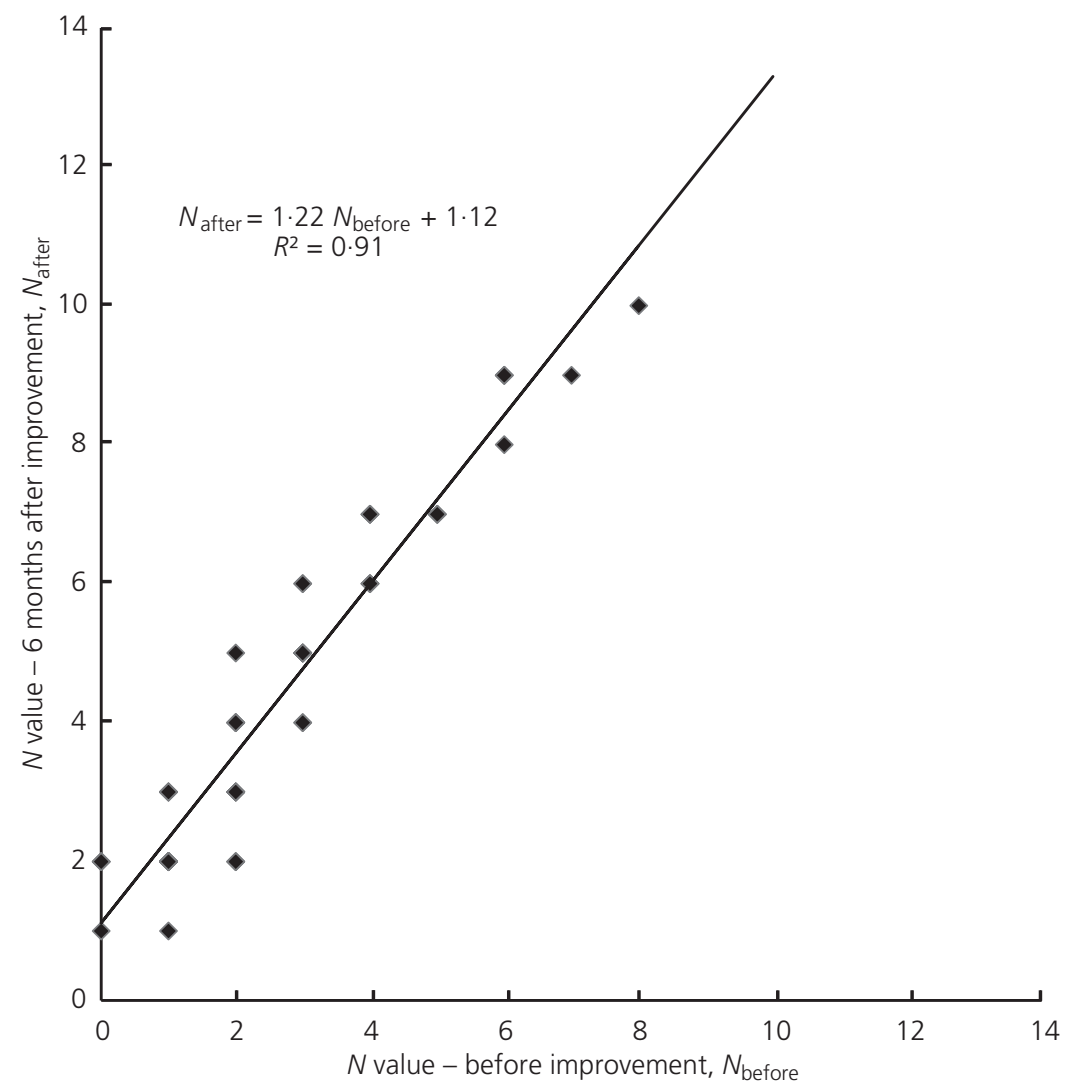

Figure 4. Variation in $N$ values before and after the improvement of the clay ground with SCs (at the centre between the SCPS)

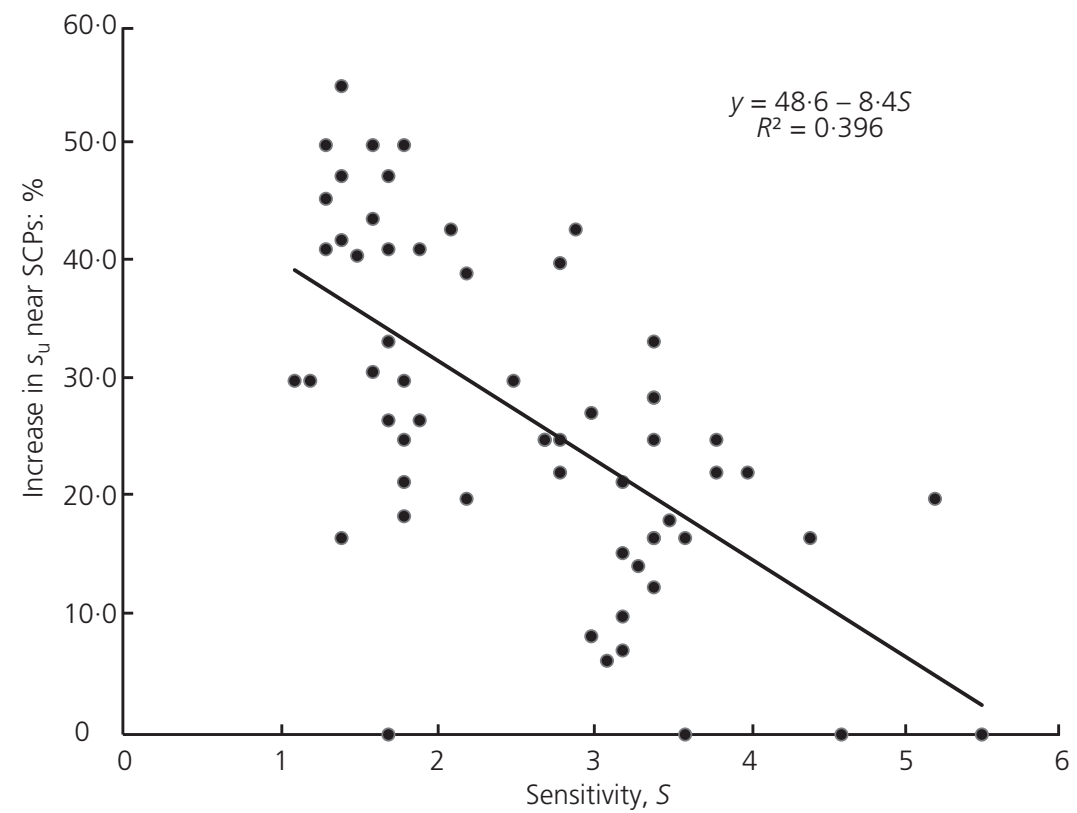

Figure 5. Variation in the sensitivity and the increase in the undrained shear strength $s_{u}$ near the SCPs (from SCPT) 


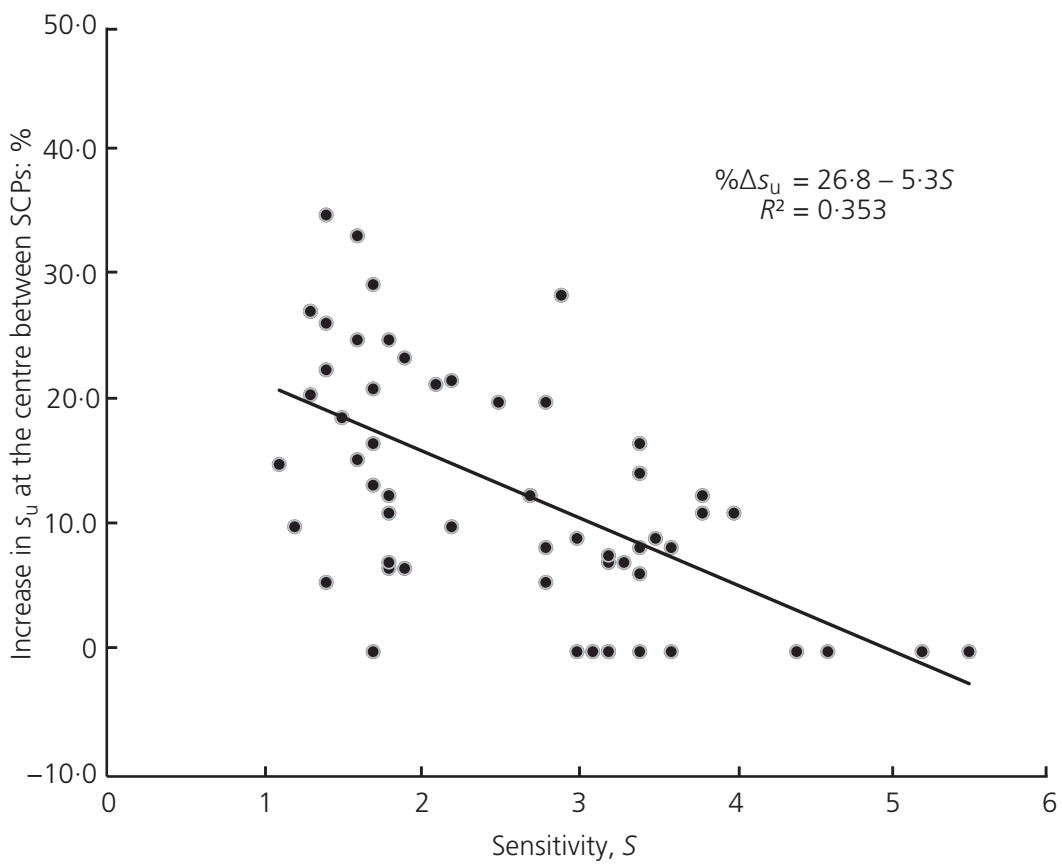

Figure 6. Variation in the sensitivity and the increase in the undrained shear strength $s_{u}$ at the centre between SCPS (from SCPT)

following expressions give the relation between the consistency index and the undrained shear strength of clay

near SCPs

6. $\% \Delta s_{\mathrm{u}}=0 \cdot 285 C_{\mathrm{I}}+9 \cdot 3$ centre between SCPs

7. $\% \Delta s_{\mathrm{u}}=0 \cdot 187 C_{\mathrm{I}}+1 \cdot 5$

The consistency index of the soil indicates the proximity of the NMC to the liquid limit of the soil. When the NMC is near the

- At centre between SCPS $\circ$ Near SCP

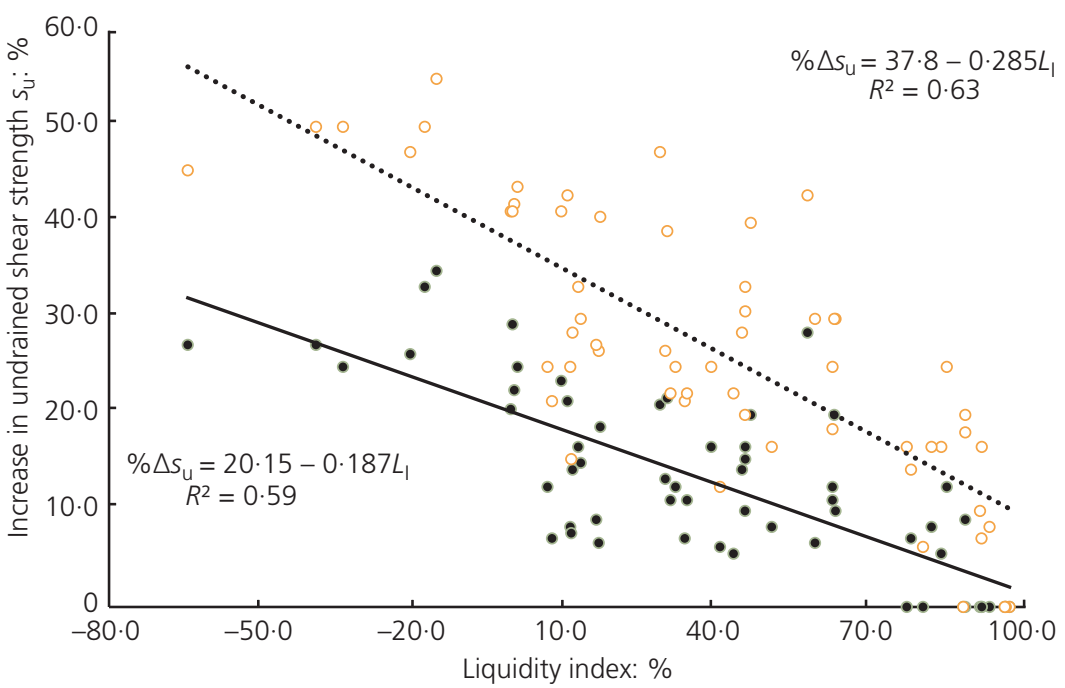

Figure 7. Variation in the liquidity index and the increase in the undrained shear strength $s_{u}$ from SCPT after 6 months 


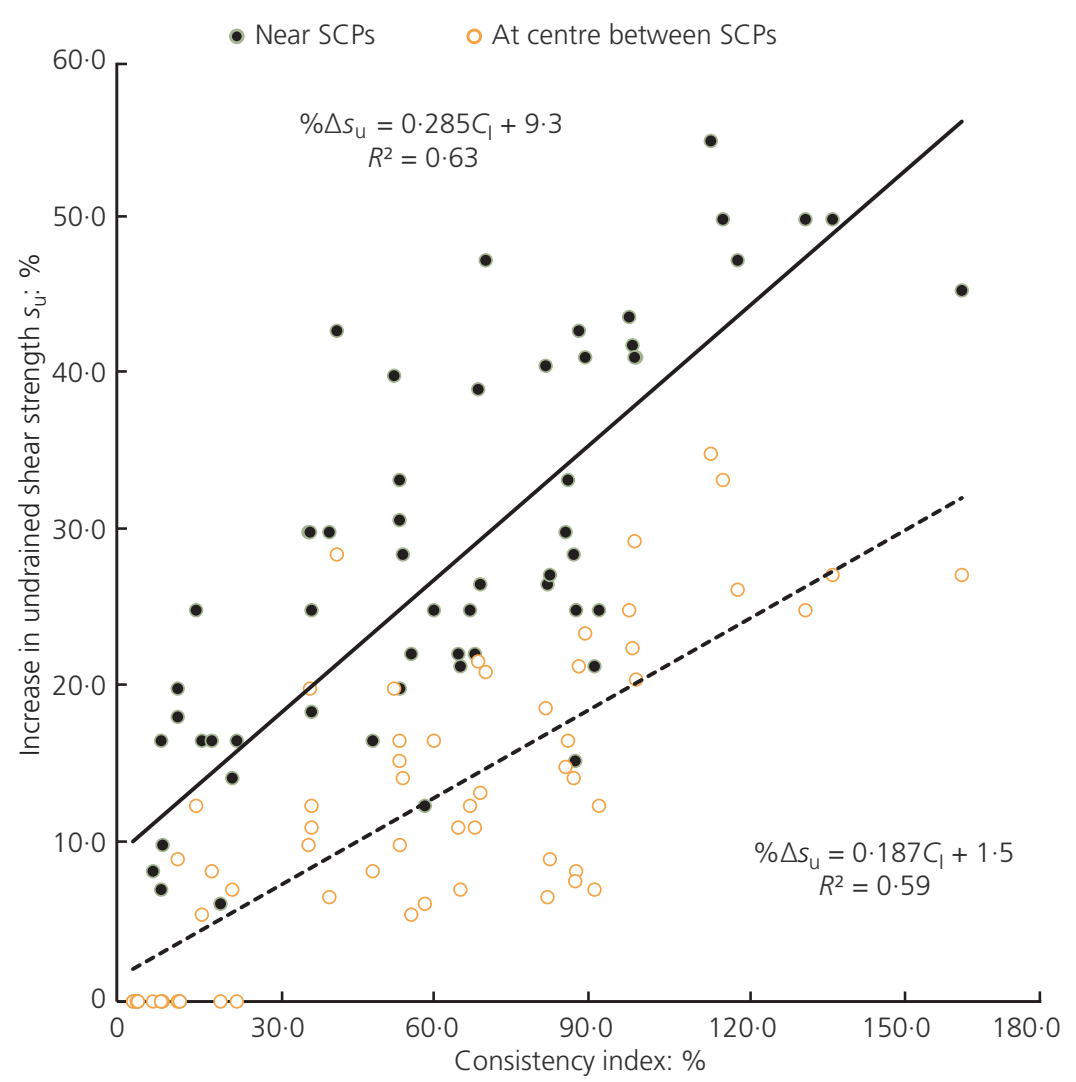

Figure 8. Variation in the consistency index and the increase in the undrained shear strength $s_{u}$ from SCPT after 6 months

plastic limit, the clay has a higher undrained shear strength. Due to the higher value of the shear strength, a larger shear strain is produced during the installation of the SCPs. This results in the increase in the setting-up effect of clay and produces a larger improvement in the undrained shear strength of clay (Yi et al., 2013).

\section{Conclusions}

Based on the foregoing discussions, the following conclusions can be arrived at.

- The undrained shear strength of the clay can be improved by providing SCPs. The improvement is mainly from the dissipation of the pore pressure developed due to the larger shear strain produced by the installation of SCPs and the increased lateral resistance due to the compression of clay.

- The SPT value of the ground improved with SCPs is given by Equation 1. For design calculations, the angle of internal friction ( $\varnothing)$ of the broken stone material can be taken as two or three times the $ø$ value of the broken stones determined from the laboratory test. This is due to the smaller diameter of the SCPs.

- The sensitivity of the clay has a significant effect on the improvement in the undrained shear strength of clay improved with SCPs. The increase in sensitivity reduces the improvement in the undrained shear strength. With clays with a sensitivity of more than $5 \cdot 5$, the improvement in the undrained shear strength of clay is negligible and can be disregarded. Only the contribution from the shear strength of the SCPs needs to be considered in the design. Since the area replacement ratio is very low, ground improvement using SCPs is not advisable for clay with a sensitivity of $>5 \cdot 5$.

- The liquidity index of soil is a good indicator for studying the feasibility of providing the SCPs in clay for ground improvement. If the liquidity index of the soil is higher, the possibility of the increase in the undrained shear strength of clay is lower. As the liquidity index approaches $100 \%$, the improvement in the undrained shear strength of clay can be neglected.

- A higher consistency index of soil indicates that clay ground is good for improvement with SCPs. In that soil, the increase in the undrained shear strength of clay is substantial. If the consistency index of clay is near zero, no improvement in undrained shear strength is possible.

- Based on the study of the soil properties such as sensitivity, liquidity index and plasticity index, the suitability of SCPs for improving the bearing capacity of clay ground can be assessed. The bearing capacity of the improved ground can be arrived at based on the combined assessment of the different correlations given. 


\section{REFERENCES}

Aboshi H, Mizuno Y and Kuwabara M (1991) Present state of sand compaction pile in Japan. In Deep Foundation Improvements: Design, Construction and Testing, STP 1089 (Esrig MI and Bachus RC (eds)). ASTM International, West Conshohocken, PA, USA, pp. 32-46.

Ambily AP and Gandhi SR (2007) Behaviour of stone columns based on experimental and FEM analysis. Journal of Geotechnical and Geoenvironmental Engineering ASCE 133(4): 405-415, http://dx.doi.org/10.1061/(ASCE)1090-0241 (2007)133:4(405).

BIS (Bureau of Indian Standards) (1973) IS 2720-2: Indian standard methods of test for soil, Part 2: Determination of water content. BIS, New Delhi, India.

BIS (1985a) IS 2720-4: Indian standard methods of test for soil, Part 4: Grain size analysis. BIS, New Delhi, India.

BIS (1985b) IS 2720- 5: Indian standard methods of test for soil, Part 5: Determination of Atterberg limits. BIS, New Delhi, India.

Black J, Sivakumar V, Madhav MR and McCabe B (2006) An improved experimental test set-up to study the performance of granular columns. Geotechnical Testing Journal ASCE 29(3): 193-199, http://dx.doi.org/10.1520/GTJ14195.

Bowles JE (1997) Foundation Analysis and Design. McGraw-Hill, Singapore.

Castro J and Sagaseta C (2009) Influence of stone column deformation on surrounding soil consolidation. In Geotechnics of Soft Soils - Focus on Ground Improvement (Karstunen M and Leoni M (eds)). Taylor \& Francis, London, UK, pp. 333-338.

Guetif Z, Bouassida M and Debats JM (2007) Improved soft clay characteristics due to stone column installation. Computers and Geotechnics 34(2): 104-111, http://dx.doi.org/10.1016/ j.compgeo.2006.09.008.

Juneja A, Mir BA and Roshan NS (2013) Effect of the smear zone around SCP improved composite samples tested in the laboratory. International Journal of Geomechanics ASCE 13(1): 16-25, http://dx.doi.org/10.1061/(ASCE)GM.19435622.0000169 .

Kitazume M (2005) The Sand Compaction Pile Method. Taylor \& Francis, London, UK.

Kulhawy FH and Mayne PW (1990) Manual on Estimating Soil Properties for Foundation Design. Electrical Power Research Institute, Palo Alto, CA, USA, report no. EL-6800.

Lee FH, Juneja A and Tan TS (2004) Stress and pore pressure changes due to sand compaction pile installation in soft clay. Géotechnique 54(1): 1-16, http://dx.doi.org/10.1680/geot. 2004.54.1.01.

Sabatini PJ, Bachus RC, Mayne PW, Schneider JA and Zettler TE (2002) Geotechnical Engineering Circular No. 5 - Evaluation of Soil and Rock Properties. Federal Highway Administration, Washington, DC, USA, report no. FHWA-IF-02-034.

Schmertmann JH (1975) Measurement of in situ shear strength state of the art report. In Proceedings of the Conference on In Situ Measurement of Soil Properties, June 1-4, 1975, North Carolina State University, Raleigh, North Carolina: Specialty Conference of the Geotechnical Engineering Division, ASCE. ASCE, New York, NY, USA, vol. 2, pp. 57-138.

Serridge CJ and Sarsby RW (2009) A review of field trials investigating the performance of depth vibro stone columns in a deep soft clay deposit. In Geotechnics of Soft Soils - Focus on Ground Improvement (Karstunen M and Leoni M (eds)). Taylor \& Francis, London, UK, pp. 293-298.

Sheahan TC, Kovacs WD and Holtz RD (2011) An Introduction to Geotechnical Engineering. Pearson, Noida, India.

Sivakumar V, McKelvey D, Graham J and Hughes D (2004) Triaxial tests on model sand columns in clay. Canadian Geotechnical Journal 41(2): 299-312, http://dx.doi.org/ 10.1139/t03-097.

Yi JT, Goh SH and Lee FH (2013) Effect of sand compaction pile installation on strength of soft clay. Géotechnique 63(12): 1029-1041, http://dx.doi.org/10.1680/geot.12.P.108.

\footnotetext{
WHAT DO YOU THINK?

To discuss this paper, please submit up to 500 words to the editor at journals@ice.org.uk. Your contribution will be forwarded to the author(s) for a reply and, if considered appropriate by the editorial panel, will be published as a discussion in a future issue of the journal.
} 